Jap. J. Psychol.,

1966, Vol. 37, No. 4, 204-218

\title{
政治的態度の構造飞関する研究 I
}

\author{
東京大学 \\ 飽鹗弘
}

\section{1. 政治的龍度の構造・類型に関するモデル}

政治的態度, よりひろくは社会的態度の構造または類 型については，種々な学問的伝統により，極めて多様な 問題意識にもとづく数多くの研究の成果として, 種々な モデルが提唱されるにいたっている.

これらのモデルについて, 次のよ5に大きく三つの流 れを区別して报くことは，個々のモデルの理解と評価に そって有効であるう。

A. 第一の流れは,「政治現象」「社会状沉」の研究の 過程に招いて，いわば補助的役割を果すために導入され たモデル群でめる。例光ば，政治様式・支配様式と政治 意識1, 文化・社会の類型と政治的態度の型 ${ }^{2}$, 労働条件・ 労務管理・労働組合などの存在形態を分析しながら労働 者の意識を解釈するなぞといった研究3が，この流れに 属する。ここでは「政治過程」「社会構造」の類型がまず めって，それに刘応した「個人」の類型が設定される。 いわば,「存在と意識」の問題に特いて, 存在の側に, 重 点が括かれている流れで,「政治学」「社会学」「文化人 類学」などの学閣的伝統による研究の大半が，この系列 に属する。

B. 第二の流れは，「社会心理的存在」の政治意識の 研究に現われるモデル群である，例光ば，政治的決定状 況（投票，政党支持など）にはたらく媒介変数の追求， 先有傾向, 準拠集団の理論などとの関連に㐨ける政治的 態度の研究なぞが，この流れ属する。いわば「意識の 相対的独立性を強調し，意識構造气れ自体の中に変革の 諸要因を追求していこうとする」流れである。「社会心 理学」の伝統による研究がそれである。

C. 第三の流れは，「行動を貫く一般法則の定立」る めざす研究の過程に招いて，一種の中間製品として散見 されるモデル群である。ここでは,「政治的態度」であ

1 水井 (1955).

2 Riesman (1950) 他.

3 福武 (1960).

4 福武 (1960).

5 㒺部 (1959).
れ，「社会的態度」であれ，「宗教的態度」であれ，終局的 にはそれらを素材に抽象される「態度」なるものの次元 なり，構造なりを，そしてその間での均衡または変革に ついての法則を,さらに「行動の原理」を, 追求すると いったことが研究の主眼とされる。いわば,「存在」は 「意識」の背景にすぎず，「存在」は「意識」を通じての み,「意識」に反映され，浸透されたかぎりに捻いて，問 題とされる.「心理学」,「精神分析学」(特に正統派)な ぞの伝統からの接近は, この流れに属する。

研究の流れからい光ば, 本研究系列は, C. の流れに 属するのであるが，そのなかで本稿は，末さに B. の流 れに岕る。すなわち,‘政治的態度」を素材として，その 制約を明らかにしつつ，その条件のなかで，ひとまず 「態度構造」の問題を検討しょうとするので岕る。これら の点については，次稿以下でふれる。

これらの流れごとに提唱されてきた政治的・社会的態 度の構造・類型のモデルについて分類し、詳細なる考察・ 批判を加えることは，今後の「政治的態度」の構造研究 のためにも有効な基礎作業となるであるらが，ここでは これらの流れより，いくつかの代表的モデルを概観し， それらのモデル群のもつ問題点をスケッチして招くにと ぞめたい。

A. の流れの代表的モデルとしては Riesman (1950) が，政治のスタイルからみた類型として提出した，いわ ゆる「情熱一能力」図式による，モラライザ一，内幕情報 屋, 熱狂型または慷慨型，無関心型とか，日高 (1960) の「社会的性格」に関する類型，すなわち，庶民的，臣 民的，市民的，大衆的，人民的の 5 つの性格型などが女 げられよう。(そのほか, Parsons 潘か (1954)の「行為 の志向の三つの様式」, Merton (1957) の適応様式の類 型に関する「目標一手段」図式なども，この流れに属す るとい兄よう.）

B. の流机は「意識調査」の設計・分析・考察の段階 で設定される，いわゆる「意見構造」のモデルであり， 代表的なものとしては，日高保か(1955) の「政治意識 スケール」, 高橋潘か(1958) の「政治的関心スケール」、 
辻村活か（1959）の「状況的 $\times$ 基底的」意見構造, 池内 (1960)の「政治意識構造」についての8つの次元などが める。またそそれらのヒエラルキー的構造を想定したモ デルとして, Kornhauser (1956) をはじめ, 高橋 (1960), 日高侸か(1964)などの「政治的行動一態度構造」に関す る図式がある。三宅(1964) の「政治意識構造チャート」 も，この系列に入る。その他 Campbell (1954) の「候 補者決定に郝子る6つの心理的变数」についての図式, 杉淰か(1954) の「権威主義的価值態度×社会主義的イ デオロギー」型のモデルなどもこの流れに含まれよう。

C. の流れの主流は, 「社会的態度」に関する因子分析 を用いた一連の研究であろう。最も代表的なものとして は，Thurstone (1934)の「保守一急進×国家一反国家」因 子モデル, Eysenck (1951) の「保守一急進×硬心一軟心」 因子モデルなどがある。同様の研究として, Carlson (1934), Johnson (1942), Eysenck (1953 a, 1953 b, 1954), Sanai (1950，1951) とか, 日本で柱Thurstone, Eysenck の追試を試みた田中 (1964) (第吕章の研究)な どがあり，これらの研究では一貫して, 最も主要な軸の 一つとして「保守-急進」の軸が抽出された旨, 報告さ れている.

一方全く類似の手続きに依りながら, Hayes (1939), Ferguson $(1939,1940)$, 日本では藤野淰か (1953), 河 村㴽加(1960), 西平(1962), 田中(1964)(第亚章の研究) などでは,「保守一急進」の軸は，必ずしも抽出されない か，または部分的には重なるがかなりニュアンスを異に する軸として，抽出されていることが明らかにされてい る(後述).

以上のごとき，種々の政治的態度の構造に関するモデ ルの考察から得られた結論のみを個条書きにして特く と, 次のごとくなろう。

(1) 日本人の政治意識の構造を考えるとき，二分モデ ル（例えば「保守一急進」のごとき）は（外国人に和い てはこれがしばしば極めて有效なのであるが）必ずしも 妥当しない。

(2) イデオロギー（例えば「保守一急進」）と性格（例 壳ば「硬心一瑱心」）による二次元モデルは，(これも外 国に招いてはしばしば有効であることが実証されている のであるが）日本に凯いては必ずしも妥当しない7。

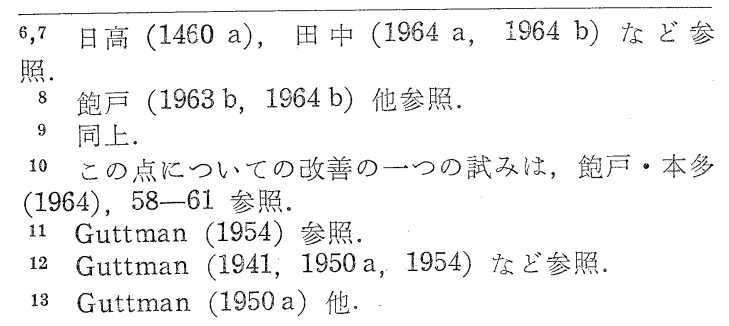

したがって, 日本人の政治意識の構造は, 多次元乞デ ル（連続型であれ，離散型であれ）による更に複雑な棈 造を想定する必要があるということになるう。そのなか でる,

(3) A. 特よび B. の流れのなかの多くのモデルがも つ染意性・非実証性.

(4) A. および B. の流れのモデルに新ける包括性， 効率性に関する保証の欠如 8 .

に関しては，大きな問題が残されている。このよ5な問 題を, 特定の立場から除去する一つの方法として採用さ れた技術が，C．の流れに路いて活躍する因子分析とい う操作的手法であるが，この因子分析乞のるのについ ても，たとえば，

(5) 尺度值の仮説, 双変正規分布の仮定, 等分散の仮 定, 主観的檕の回転に特ける染意性など, 多くの統計数 理的弱点, チンセンスを含む ${ }^{9}$.

また，その利用の実状に抒いても，

(5) 朝の偏重 (直交軸への偏執を含的て) ${ }^{10}$. などの点が，批判されねね゙なるまい。

以上の久陷を, 特定の立場からにしろ, 改善するため の方法論の追求は, 一つの重要な課題であろう。この小 論の一つの目的は, そのよ5な方法論の閉発と, そのよ らな方法論にもとづく政治的態度のモデル構成，执よび その有效性の検討に离る。

\section{2. ガットマン一林の数量化テデル}

態度研究の一つの分野に, 「態度測定」なる名のもとに 概括されている一連の研究が岕る。この分野での主要な る関心は，「単一領域に郝ける態度への，一次元的接近」 であるということができよう、Thurstone の等現間隔 法, Likert の方法, Guttman の尺度解析法などに関す る研究は，穴代表的なるのである。

当然のことながら，このような「一次元的接近」(多 くは，好意的一非好意的といった軸の上に諸態度を位置 づけよとする）は，多くの限界をるつ。その批判は， (1)「質への逃遌」11（例党ば，深層面接などによる質的分 析への傾斜，量的分析との性急なる訣別）とか，(2)領域 間分析への転向（例えば 1.のC. の流れ）などを結果 しているように思われる。そこで第三の方向は, (3)「単 一領域内に和ける多次元的接近」で，それを試及たのが， Guttman の「主要素解」による接近 ${ }^{12} て ゙ あ る$ 考学ら れる、そこで以下, ごく簡単に，この Guttman の方法 を検討して和くことにしたい。

Guttman の尺度解析法に晾故万主要な概念は，完全 尺度（完全に内的整合性をるつ尺度）という考光方で女 万丂 $5^{13}$.

例えば， $n$ 個の 2 分アイテムよりなる尺度で，そのう らの岕らゆ 2 個づつのアイテムの組み合わせによる四 
分表に関して，常に0である項(zero cell)があるならば, その尺度によるタイプ (scale type) は，完全にある一 次元連続体の上に，矛盾なく一列に並べることができる というものである。このようにすることにより，尺度に よるタイプの数も， $2^{n}$ 個より， $n+1$ 個にと激減する。 この完全尺度の理論は 3 分アイテム, $m$ 分アイテムに関 しても全く同様に拡張適用されうる.

しかし，現実には完全尺度などというものは，社会科 学の領域ではほとんど得られない14。そこで, 内的整合 性に対応する指数（再現性係数） $R$ なるものを定義し, $R$ が十分大なるとき (scalable とは $R \geqq 0.90$ のとき， quasi scalable とは $R \geqq 0.85$ のとき）この尺度を完全 尺度と見做して，完全尺度の理論を適用しょうとするわ 汿である。

このような発想を更に徹底させるならば，このRが， 最大になるような, アイテム・カテゴリー(の weight) のまとめ方（すなわち score の与方）を工夫するとい うことになる ${ }^{15}$. そこで Guttman の導入したモデルは，

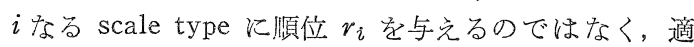
当な $x_{i}$ なる数量を与兄, $\sigma^{2} x i$ を一定とい5条件のもと で16, ずべての $\left|x_{j}-x_{k}\right|$ が最大になるように, 従って subgroup 間の差を最大にし, subgroup 内の差を最小 にするよう，すなわち相関比 $\eta^{2}$ が最大になるようにす るという考光に至る。これが Guttman の数量化法のモ デルであり，これは，内的整合性方程式 ${ }^{17}$ なるものを解 くことによって果される.

この数量化のモデルを，完全尺度に適用したところ， 最適解 ( $R$ が最大になるような数㨁の組 $\left.{ }^{1} X\right)$ が常に存 在し, それはもとの順位の組 $r$ 対し monotoneな回 帰を示すことが明らかにされた ${ }^{18}$. 次いでRが最大にな

14 社会科学の領域で，完全な尺度をなすアイテム群と いうのは, 所詮同じことをきいているにすぎないという ことになり, 従ってアイテム群を用いても, 単独アイテ ムによるよりほとんど情報は増えないことが多いといわ れる。

15 Guttman (1950a) 他.

16 何故なら, $x_{i}$ をいらでも大きくしていけぼ, $\left|x_{j}-x_{k}\right|$ は, いくらでも大きくなるから.

17 The equations of internal consistency. 即ち,

$$
\rho=\frac{\sum_{i=0}^{m} \sum_{j=1}^{2 m}\left(x_{i}-\frac{1}{N} \sum_{n=0}^{m} x_{h} f_{k}\right) \cdot}{\sqrt{\left.\left.\left[n y_{j}-\frac{1}{N n} \sum_{k=1}^{2 m} y_{k} F_{k}\right) f_{i} g_{j} e_{i j}-\frac{1}{N} \sum_{n=0}^{m} x_{h} f_{h}\right)^{2} f_{i}\right] \cdot}}
$$

なる ○を最大にする $x_{i}$ (故に $y_{j}$ も) を求めることに相 当する。
る，いわば次善解（ベクトル ${ }^{1} X$ 以外で， $R$ が最大にな る数值の組 $\left.{ }^{2} X\right)$ が存在し, それはもとの順位の連続体 rに対しU字型（またはV字型，J字型，逆J字型）の 回帰を示すこと, 更に次々善解 $\left({ }^{3} X\right)$ が存在し, それは $r に$ 対してN字型（または逆N字型）の回䚻を示すこと， 一般に $n$ 個のアイテムより成る尺度に関しては, $n$ 個の 解ベクトルが存在し, 第 $j$ 番目の解の $r へ の$ 回帰曲線 は, $(j-1)$ 個の極点 (極大点末たは極小点) bending pointをもつことなどが，明らかにされた ${ }^{19}$. Guttman

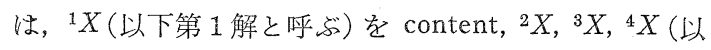
下第 2 解, 第 3 解, 第 4 解と呼岕) を intensity, closure, involution と命名し, その全く操作的に導出さ れた数学的解 (主要素解 principal component) に, 心 理学的な意味づけを与学ことに成功している ${ }^{20}$. 更に, このような数值は, 用いられたアイテムの性質执よび関 連に完全に依存するため, 別のアイテム群が用いられた ならば,全く別の scale type が得られるかもしれない. そこで，ぞのようなアイテム群を用いても変異しない，

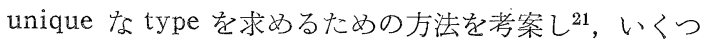
かの資料によって, その方法の妥当性をも検証してい $る^{22}$. Guttman の「心理学的基本機能」 (content, intensity, closure, involutionの 4 つ), 叔よびそれらの 組久合わせによる「絶対心理類型」23 といった概念は, このように, 用いられたアイテムに依存しない, 不変の unique な次元および類型の抽出を試みた，多くの実証 的研究の結果, 導入されたものである.

しかし, Guttman の理論と方法には, 論理的には優 れているが，実際に適用し応用する祭には，多くの難点 がある、この詳細は, 別の機会に論ずることにして, 要 点のみを箇条書きにして列挙すると, 次の如くなる。

(1) 尺度化可能性を前提とすること.

(2) 個々の資料を必ず数量化するわけではないこと。

(3) 得られた幾つかの尺度同志の非対応性.

(4) 異なる尺度ごとのカテゴリ一数値の比較不能性.

(5) 類型設定上での混乱・複雑性和よび非効率性.

そこで, この Guttman の「完全尺度の理論」を発展 18,19 Guttman(1950a，1954)参照. 当然のことながら, アイテム・カテゴリーが, 完全尺度をなさないときには, ぞのような回帰型が得られるかは，全く不明である。

20 Guttman (1950 a) で第 1 解, 第 2 解について, Guttman (1954) で第 3 解, 第 4 解について, 論じられ ている.

21 これが『弓矢法』(“the bow-and-arrow technique”) と呼ばれる「強度分析」によって代表される一連の回帰 分析姿用いた方法である。

22 Suchman (1950) に最詳しい.

23 Guttman (1954) 参照. 
させた，いわば「不完全尺度の理論」が，林知已夫博士 により提唱されていることに着目したい24. 筆者は上記 5 つの難点を, 理論的・実用的見地より克服するための 方法論をこの「不完全尺度の理論」の新しい適用方法の 提案という形で提出したい.

\section{3. 新しい方法の提案 一一逆尺度数量化一}

尺度解析 一数量化 一尺度間回帰分析という Guttman の方法（完全尺度の数量化理論に基づく尺度数量 化の方法）のもつ幾多の現実上の制約飞解消して, 実際 に使用可能なものとするため, 次のような方法を考学て みる。

(1) いくつかの content ${ }^{25}$ に対し, その intensity closure, involution ${ }^{26}$ と論理的に想定可能なアイテム 群(これは尺度をなしている必要はない27) を設定する。

(2) それらのアイテム・カテゴリーを, 一括して数量 化を特こなう。

(3) 得られた「主要素解」の第 1 解と content との回 㷌が monotone であるかどらかをチェックする。

(4) 第 1 解の数值屯たは content のパーセンタイル そ, 第 2 解, 第 3 解, 第 4 解との相関図 scatter diagram 娄描き intensity, closure, involution に相等する回 㴆を示すアイテム群（または単独アイテムにても，アイ テムの組又合わせ型にても可 ${ }^{27}$ ) を抽出する.

(5) 抽出された諸変数間の関連を分析する.

(6) 第 1 解, 第 2 解, 第 3 解, 第 4 解などを組又合わ せた類型の設定・考察を扣こなら。

(7)これらの諸変数・諸類型と, 社会的特性との関連 を, 記述し, 考察する. (以上数学的分析).

\footnotetext{
24 Hayashi (1950, 1952, 1954) 他参照.

25 Guttman の法では, 常に一つの contentを中心 に, 数量化, 考察を执こなうが, この方法では, 複数の content を, 同時に数量化, 考察し得る.

26 involution は, 第 4 解に与えられた「心理学的基本 機能」である。詳しくは, Guttman (1954) 参照. 然し 一般には第 4 解が適用できる資料は極めて少い。

27 即ら, 一問への回答肢でるよいし, 数問への尺度を なさない反応型でもよい。

28 調査項目の設定, 調査図式の構成などは, 同委員会 全員の協議により执こなわれたるのであり, 本論稿に対 しても, 同委員会の皆さんからは, 多くの有益な示唆を 戴いた。ここに深く感謝の意を表させていたたくくな挔， 同委員会の構成は，次のと5りである。

主 査：日高六郎 (東大教授, 社会学)

委 員: 福島新吾 (專修大教授, 政治学)

委員: 大島太郎 (専修大助教嗳, 政治学)

委 員：松下圭一 (法政大助教授, 政治学)

委員: 飽戸 弘 (東大助手, 心理学)

29 これらについての詳細は, 日高ほか (1964) 在参照 されたい。
}

(8) 以上の諸事項が, 選ばれたアイテムに依存する事 柄であるか, アイテムのサンプリングの方法に関係なく 存在し5る事柄で岁るかを, 回帰分析・尺度構成の操作 によりチェックする ${ }^{21}$ 参照 (心理学的分析).という手続 きをとる。

すなわち Guttman の方法と異なるのは，手続きとし

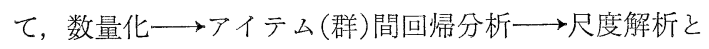
いう順序の逆転を主張している点であり, しかもこの尺 度解析の部分 (従って完全尺度に関する理論) は, 数学 的分析が，アイテムにどの程度依存するかをチェックす るための, いわば一般化のための付加的な, 第二の独立 した段階（80段階）と考光ている点である.

以上のごとき問題意識に基づき, 理論的に提唱された このような新しい方法論を,「政治的態度の構造」の記述 と考察に適用することにより, 実証的に 1. でられた種 々の「政治的態度の構造・類型のモデル」について検討す るとともに，2．３．で提出した筆者の「方法論」につい ての検討をる，併せ試みたいというのが，本稿の主意 である。

\section{4. 政党支持と政治意識の動向についての調査}

以下に紹介する資料は, 1963 年 12 月, 社会党選挙対 策委員会の委嘱を受け, 平和経済計画会議内に設けられ た「政治意識調査委員会」28 が, 東京と千葉に㧊いてお こなった世論調查の結果の一部を, 筆者が再解析し, 考 察を加えたものである、この調査の詳細な報告は, 日高 添か (1964) を参照されたい.

調查実施の概略は, 次のと扣りである.

(1) 調查期日：1964 年 2 月 14 日-2 月 20 日

(2) 調査地域和よび調査対象 :

イ）東京都 23 区内居住の有権者 800 名（回収 67 $\%$ )

口) 千葉市内居住の有権者 840 名（回収 $76 \%$ )

(3) 標本抽出法: 選挙人名簿上り (層化) 二段比例確 率抽出

(4) 調查方法: 訪問面接聴取法

調查図式执よび調查アイテムは, Fig.A のと和りで ある29.な抏，実線で囲屯れたアイテムは，本解析に採 用されたもの, 点線で囲李れたアイテムは, 本解析で除 外されたもの，波線で国まれたアイテムは，関連分析さ れた社会的特性である。

個々のアイテムの具体的質問文就よびカテゴリー（回 答肢)については割愛する29. 標本構成, 単純集計結果 扣よび主要なクロス集計の結果, 項目間相関係数などに 関しても，叙述上特に必要のない部分は割愛する ${ }^{29}$.

全体として，アイテムは，5つのサブ・レベルに分割 されている、すなわち，I．政治行動，正．政党支持, III. 政治意識, $\mathbb{N}$. 生活意識, $\mathrm{V}$. 社会的特性, がそれ 
FIG. A Variable cluster.

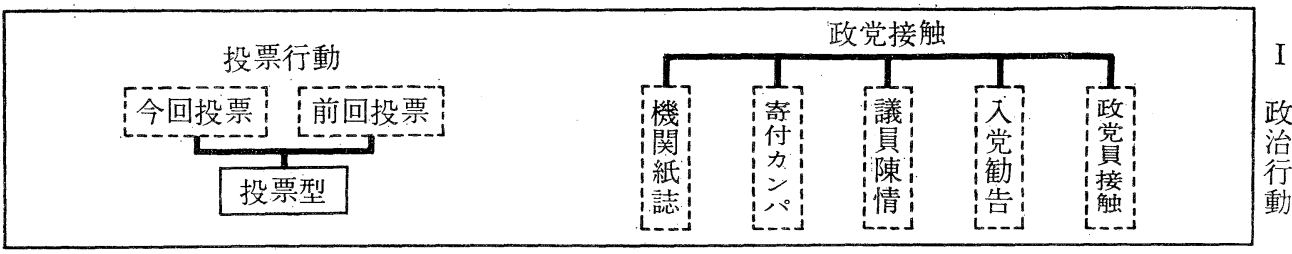
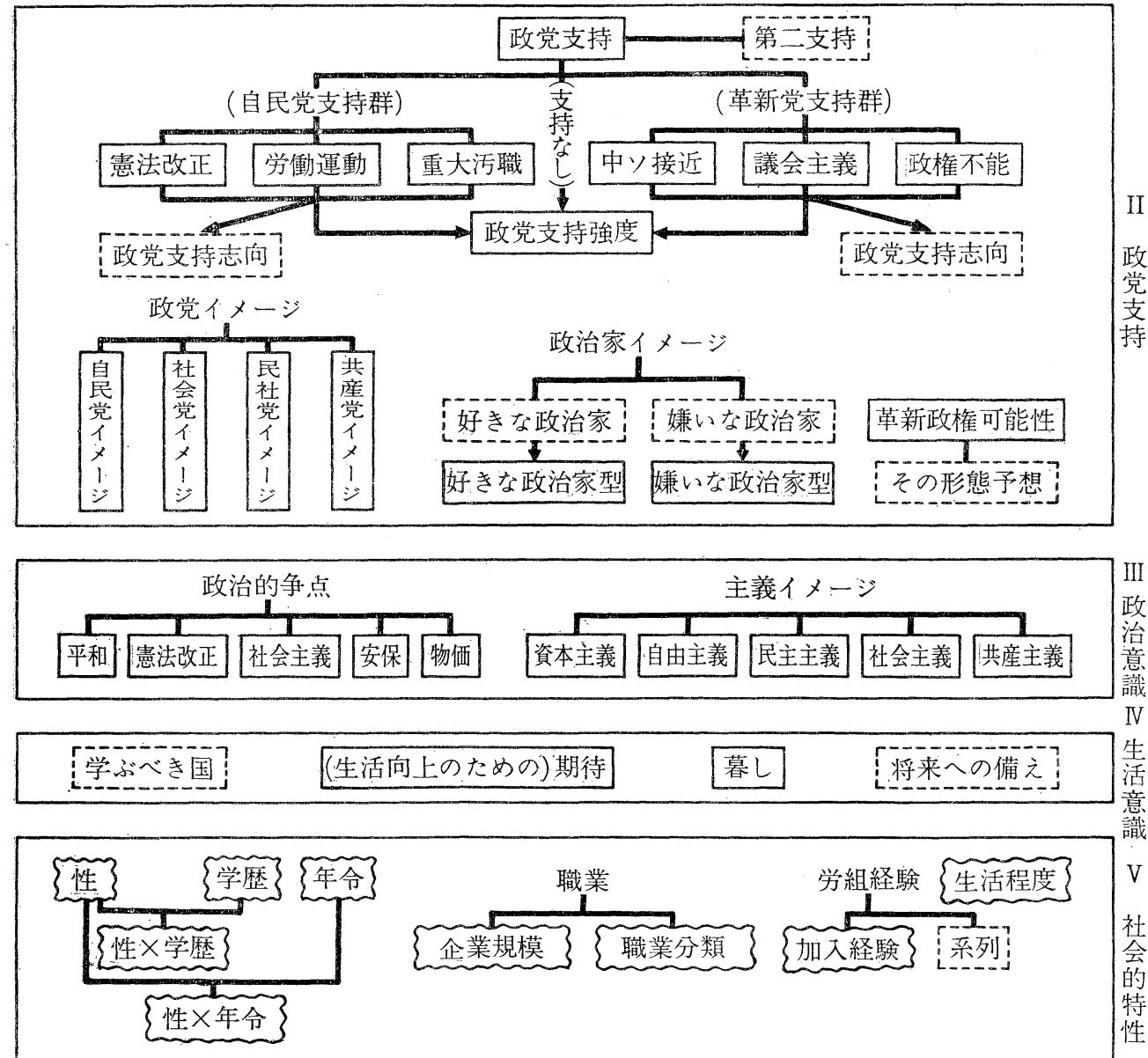

FIG. 1 Pure indicators

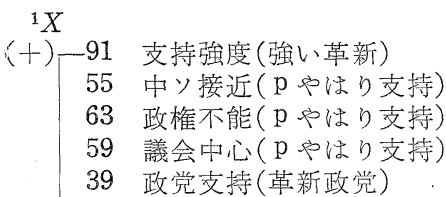

${ }^{2} X$
(十)—-92 支持強度（支持なし）
36 政権見透(わからない)
40 政党支持 (支持なし)
95 好きな政治家(いない)
81 投票型 (稁権)

38 政党支持(自民党)

47 労㗢望動 ( ( や汇り支持)

51 重大泒職 ( c や注り支持)

43 憲法改正 (c p注り支持)

(一)-88 支持強度(強い保守)
${ }^{3} \mathrm{X}$

$(十)-61$ 政権不能 $(\mathrm{p}$ 支持しなくなる)

89 支持强度 (弱い草新)

62 政権不能( $\mathrm{p}$ 力からない)

53 中り接近 ( $\mathrm{p}$ 支持しなくなる)

57 議会中止 $(\mathrm{p}$ 支持しなくなる)

85 保守得点(最高点)

49 重大污職( c 支持しなくなる)

82 保守得点(最低点)

41 憲法改正 ( c 支持しなくなる)

55 中ソ接近 ( $\mathrm{p}$ やはり支持)

45 労働運動 (支持しなくなる)

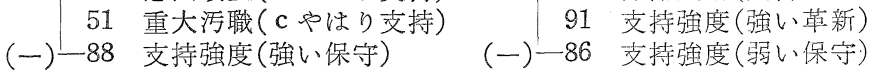


TABLE 1

Solution vectors (weight) and ranges

(Tokyo)

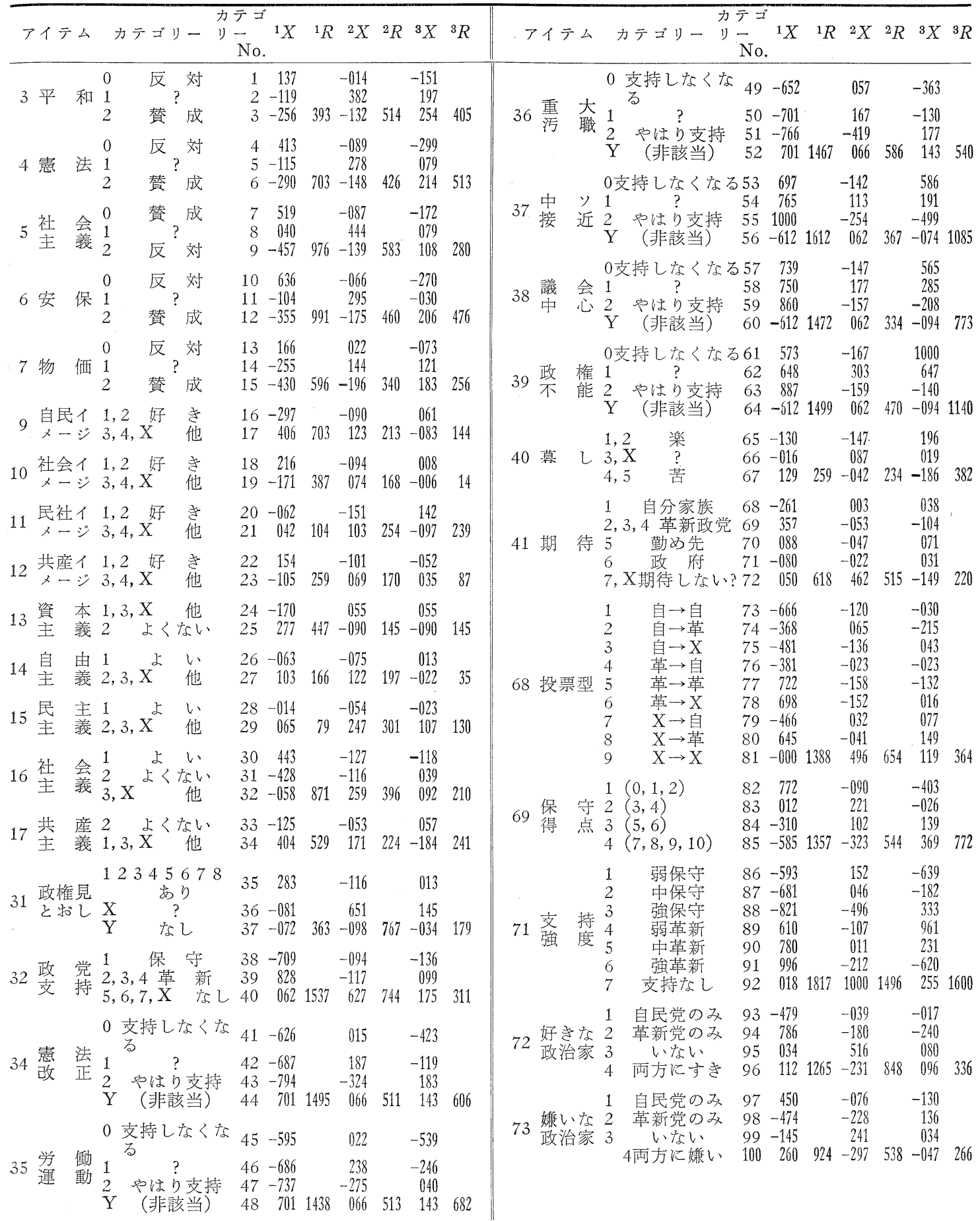


TABLE 2

Solution vectors (weight) and ranges

(Chiba)

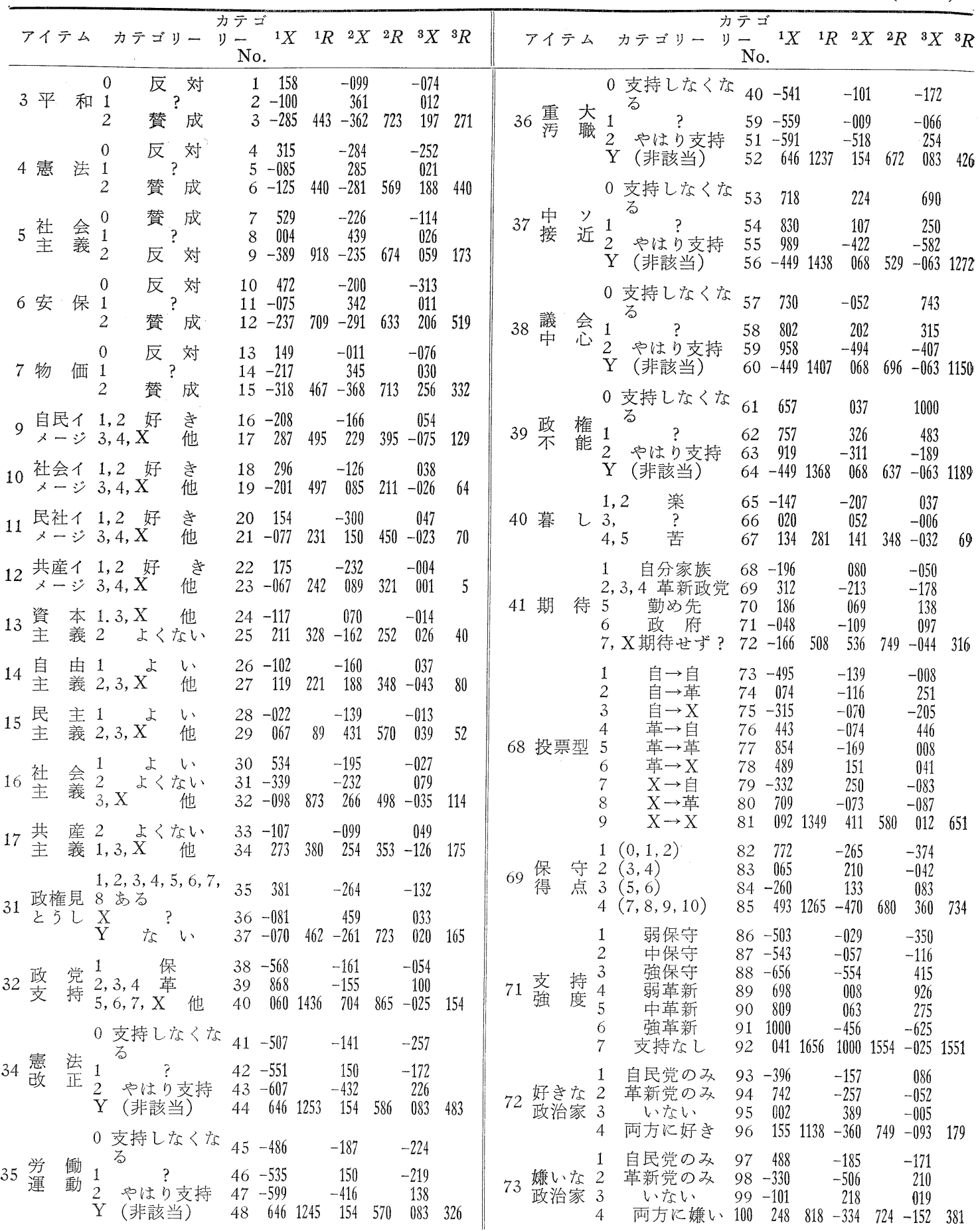


TABLE 3

Correlations

(Tokyo)

\begin{tabular}{cccc}
\hline & ${ }^{1} X$ & ${ }^{2} X$ & ${ }^{3} X$ \\
\hline$\rho^{2}$ & 0.3562 & 0.1356 & 0.1100 \\
$\rho$ & 0.5968 & 0.3682 & 0.3316 \\
$\bar{x}$ & 0.0000 & 0.0000 & 0.0000 \\
$\sigma^{2} x$ & 0.0729 & 0.0041 & 0.0036 \\
$\sigma_{x}$ & 0.2700 & 0.0642 & 0.0602
\end{tabular}

でありこれら5つのレベルはヒエラルキーをなし，下 へ行く汪ど基底的・一般的要因，上へ行くほど状況的・ 特殊的要因といった想定に基づき，これらレベル内での 整合性, レベル間の連関性の追及も, 一つの主要な課題 とされた。な和, 以下の解析に用いられたアイテムは 28 個 (Fig. A 参照), 延べカテゴリ一数は 100 個で女 る。

\section{5. 政治的態度構造の基本的次元 一一結果及び考察(その一) -}

前述のごとき $(2,3$ 参照) 数量化の方法により, 100 のアイテム・カテゴリーに対し, 3 次元の数值の組 ${ }^{30}$ $\left({ }^{1} X,{ }^{2} X,{ }^{3} X\right)$ が与觉られた。これが Table 1 特よび Table 2 である.

これら 3 つのベクトルは，対等に比較できるように， すべてのアイテムに执いて，平均が 0 になるよう変換し てある ${ }^{31} \cdot{ }^{1} R,{ }^{2} R,{ }^{3} R$ は, 各アイテムの ${ }^{1} X,{ }^{2} X,{ }^{3} X$ での レンジである ${ }^{32}$

な叔, これらの第 1 解, 第 2 解, 第 3 解に対応する相 関係数 $\rho$ 和よび, 個人の各次元ごとでの与えられた数值 の平均, 分散を, 東京と千葉別に算出したものが, Table 3, Table 4 である.これらの点については後にふれる が， ${ }^{i} \rho$ 就よび ${ }^{i} \sigma_{x}$ は ${ }^{i} X$ の分類の効率を示す指標であ るから，これらの表より，三つの解は，ともにかなり良

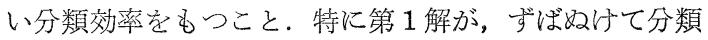
効率のよい次元であること（東京・千葉とも ${ }^{1} \rho \div 0.6$ ),

30 「数学的主要素解」 (mathematical principal components) ${ }^{i} X$ は，ここでは $\left({ }^{i} x_{1},{ }^{i} x_{2} \ldots \ldots{ }^{i} x_{100}\right)$ なる 100 個の要素より成るべクトルであるが，以下このように略 記する。

31 例光ば Table 1 の「憲法改正」では，賛成：195, 反対：182，どちらともい光ない or わからない: 162, であるから，この $i$ なるアイテムの ${ }^{1} X$ についての平均 值 ${ }^{1} \bar{x}_{i}=1 / n_{i} \sum_{j=1}^{3} n_{i j}{ }^{1} x_{i j}=1 / 539[195 \times(-0.290)+182 \times$ $0.413+162 \times(-0.115)]=0.00$ となる.

32 これは個々のアイテムの, 各因子（基本次元）への 寄与の大きさ（偏相関に相当）と考光ればよい。

33 註 21 及び3.の8)参照.

34 註 20 参照.
TABLE 4

Correlations

\begin{tabular}{cccc}
\hline & ${ }^{1} X$ & ${ }^{2} X$ & ${ }^{3} X$ \\
\hline$\rho^{2}$ & 0.3401 & 0.1658 & 0.1090 \\
$\rho$ & 0.5836 & 0.4073 & 0.3301 \\
$\bar{x}$ & 0.0000 & 0.0000 & 0.0000 \\
$\sigma_{x}{ }^{2}$ & 0.0516 & 0.0096 & 0.0025 \\
$\sigma_{x}$ & $0.227 \mathrm{I}$ & 0.0980 & 0.0503
\end{tabular}

次いで第 2 解 (ともに ${ }^{2} \rho \div 0.4$ ) と第 3 解（ともに ${ }^{3} \rho \div$ $0.3)$ の順に, 效率はやや下るが, 社会現象の問題に数量 化理論を適用した例としては，充分よい効率であること がわかる．従って，以下の考察に沶いては，これら三つ の解を全て，含めて検討していくことにする.

Table 1，2，3，4 を通じて，東京と千葉では，顕著 な傾向差は殆んど認められないことは, 委ず注目される. 後述のごとく. 個々の次元の分布状況に関しては, 東京 と千葉ではかなりの差異が見られることになるが（次稿 以下にて詳述), 個々のアイテム (カテゴリー) 間の関連 構造, 主な次元の質的特性に関しては, 東京と千葉の間 に，殆んど差異はないことが明らかになった。これは， 本研究結果の, 一つの重要な成果であると考觉られる.

従って, 以下の考察に和いては, 東京の結果について のみをまず検討することにしたい。東京と千葉との間で 特に明確な差異のみられる点については，後に改めて吟 味することにしたい。

さて，これら三つの「解」の心理学的意味つけを，仮 にして拉くことは，以下の考察に便利であろう。そこ で，各次元ごとに，負荷量の大きいアイテム・カテゴリ 一を抽出し，一覧表にしたものが，Fig. 1 である。

Fig. 1 より, 得られた三つの次元の意味を解釈する ¿,

(第 1 解 : 革新一保守の次元 (PRO-CON)

$\{$ 第 2 解 : 無関心一関心の次元 (IND-INT)

第 3 解 : 革新批判一保守批判の次元 (P.C. -C. C.) と名づけるこができよう。これらの三つの次元は，互 いに独立であり, 個人の政治的態度の弁別と記述に最も 効率のよい次元であることが, 数学的に保証されている ことは，前項で述べたと抮りである。これら三つの次元 は, アイテム・カテゴリーと独立に確定されうるという 保証をらること ${ }^{33}$ が必要であるが, 一応, 政治的態度に 関する「心理学的基本次元」 $\rfloor^{34}$ と仮定することはできよ う.これが, 本研究結果からの主要な仮説の一つである.

\section{6. 基本的次元の連関構造 一一結果及び考察（その二－ -}

次に，これら三つの基本的次元間の連関の状沉を, 考 


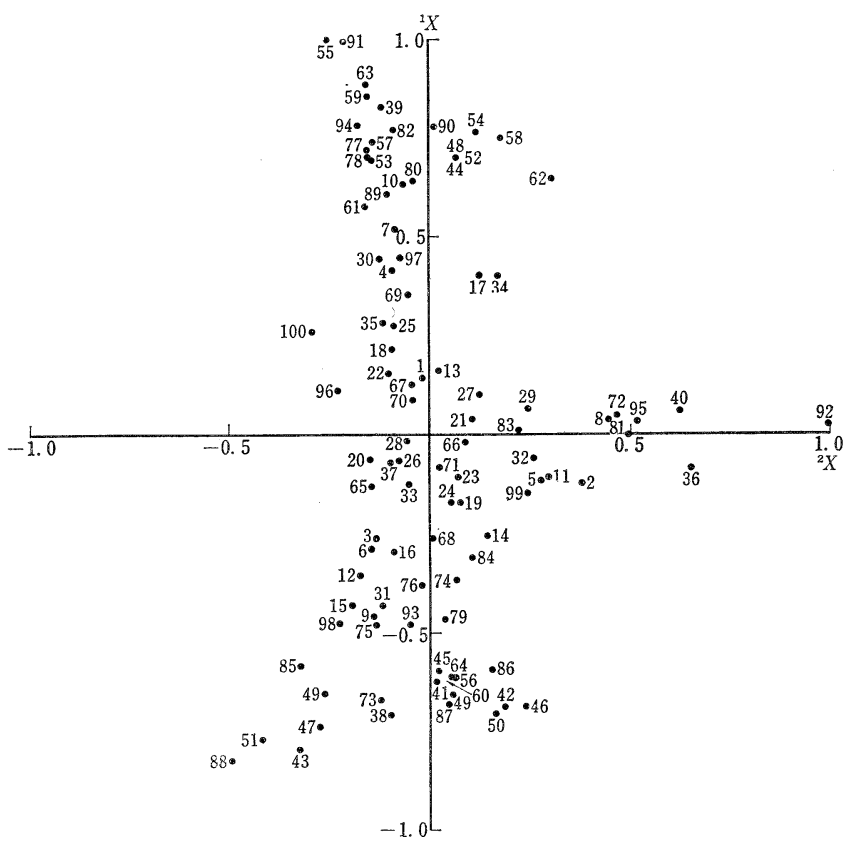

FIG. 2 Scatter diagram of relation between ${ }^{1} X$ and ${ }^{2} X$.

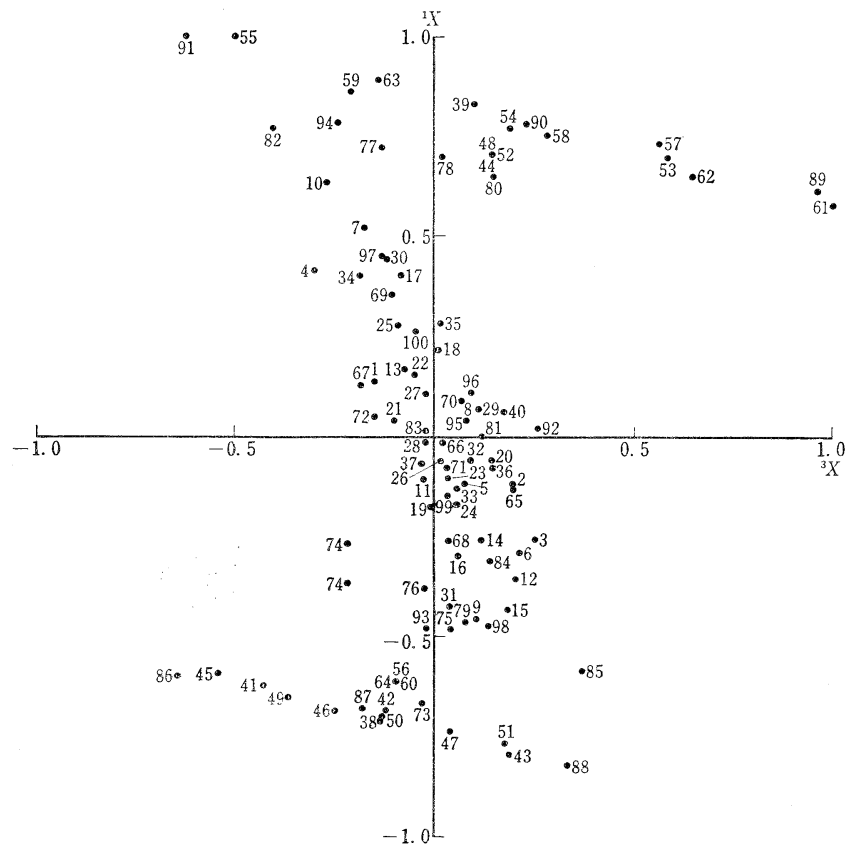

FIG. 3 Scatter diagram of relation between ${ }^{1} X$ and ${ }^{3} X$.
察することにしよう. Fig. 2, 3，4は， これら三つの数学的主要素解の数値による 相関図である。ポイントは, 100 のアイテ ム・カテゴリーのすべてについてプロット されている. 図中の数字は Table 1, 2 の カテゴリーNo. (一貫番号) である.

これらの図からは，「三つの基本的次元 は，互いに殆んど連関はない」すなわち， 相関係数 $r \doteqdot 0$ ということ以外には，特別 な関係はみられない。

これは，用いられた 100 個のアイテム・ カテゴリーが予想ど和り完全尺度（または 擬似尺度）をなしていないことを示すもの である゙

また，Fig. 2-Fig. 4 では，テイテム。 カテゴリーの数は延べ 100 個で, 煩瑣に過 ぎる、そこでまず三つの次元を通じてレン 湆の大きいアイテムをいくつか選び ${ }^{36}$,以下 順次考察していくことにしょう。

\section{7. 政党支持態度の構造}

一一結果及び考察（その三）-

当然予想されるごとく, 政治的態度の弁 別に最も效率のよいアイテムは，「政党支 持」に関するアイテム群で岕った，特に 「政党支持強度」 ${ }^{37}$ は三つの次元の何れに 扮いても，レンジは最大で岁る(Table 1, 2 参照).

そこでまず，「政党支持強度」を中心に， それと関連の深い「政党支持」乱よび「保 守度」38 の三つのアイテムを抜き出して, 以下，考察することにしょう。

これら三つのアイテムの第1解のウェイ $\checkmark$ metric component weight (Table 5

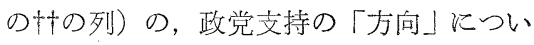
35 すべてのアイテム・カテゴリーが，完 全尺度をなすときには，規則正しい回帰型 が得られるが，それ以外の場合には，ぞの よ5な回帰型が得られるかは不明であるこ とは前述のとうりである（詿18, 19 参照)。 36 レンジの小さいアイテムそいうのは, その次元に招いて，人々の政治的態度の弁 別に対する寄与が小さいアイテムであり， 従って政治的態度構造の記述にとって, 効 率の低いアイテムである.

376 つの「政党支持」に関する質問への 回答型より合成した型。

385 つの「政治的争点」に対する暨問上 り合成した得点である。 37,38 は，詳し くは日高他 (1964) 参照。 


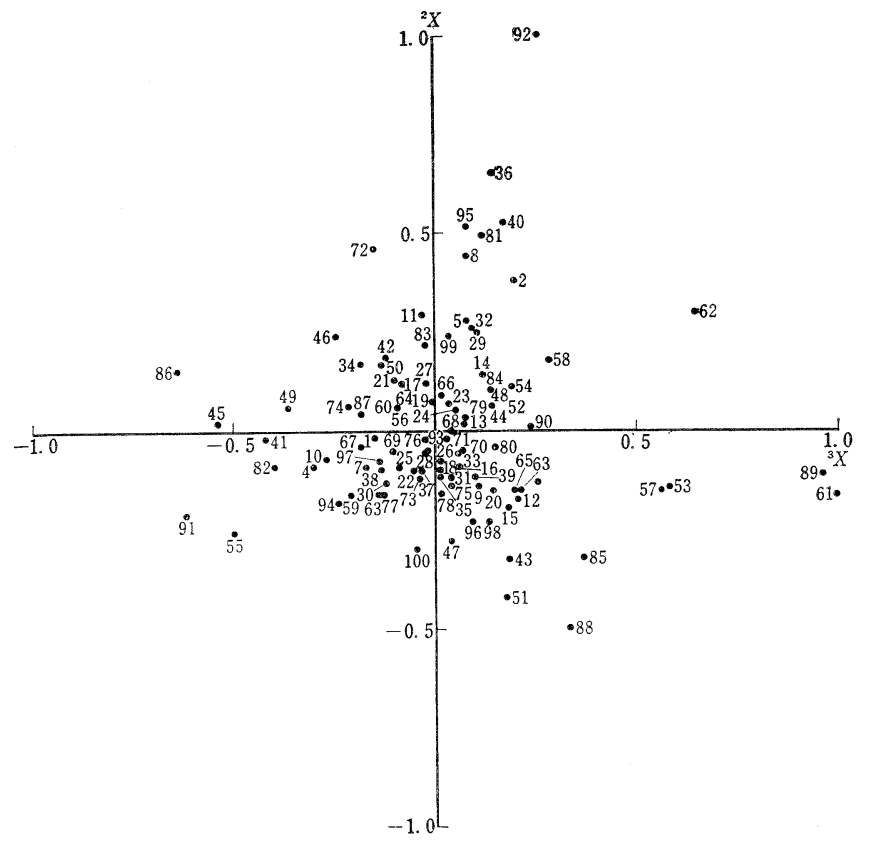

FIG. 4 Scatter diagram of relation between ${ }^{2} X$ and ${ }^{3} X$.
のウェイトがプラスであれば“革新的”で， マイナスであれば“保守的”と考觉てよさ そうである ${ }^{40}$ 。また，第 1 解のウェイトを むって, content percentile に代用させ, 以下の分析・考察を行らことにする

すなわら，第 1 解は政党支持の「方向」 に対応して特り，Guttman のいう完全尺 度における第一の成分 CONTENT に相当 するものであることが明らかにされた。

次に，政党支持の「方向」（第 1 解のウェ イト）と，第 2 解のウェイトとの関連をみ てみよう (Fig. 6).

三つのアイテムのいずれに括いても，第 2 解の第 1 解への回㷌はU 字型またはV字 型を示し, ここでも Guttman が完全尺度 をなすアイテム群に関して, 理論的・経験 的に導出した第二の成分 INTENSITY と, この第 2 解は極めて類似の機能を果してい ることがうかがえる42. しかも，この第 2 解が政党支持の「強度」に対応しているこ とは，明らかである43.
てのパーセンタイル content percentileへの回帰は Fig. 5 のごとくなる.

Table 5, Fig. 5 より, 第 1 解のウェイトは, content percentile に単調 monotone な回帰を示していること が確認された39.乙かも，“支持なし”(No sup.特よびN) の第 1 解のウェイトは殆んぞ 0 に等しい. 従って第 1 解

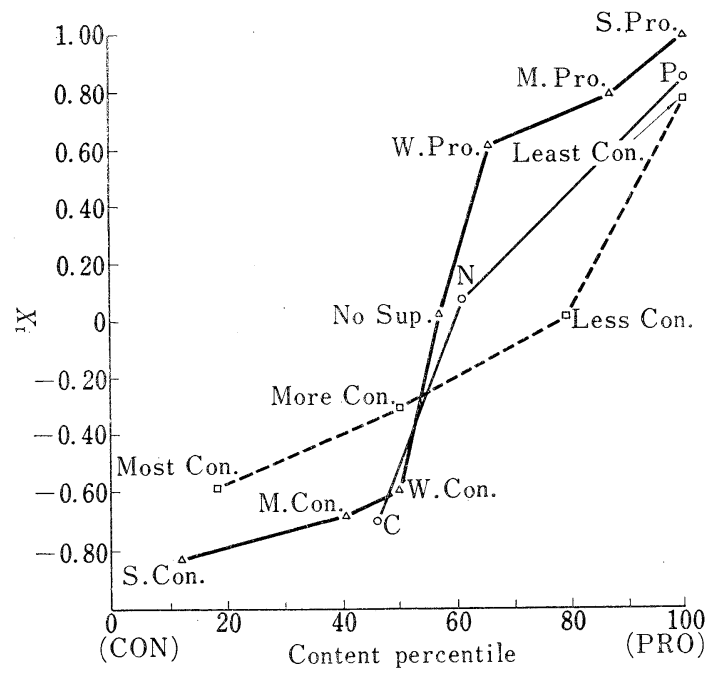

FIG. 5 Regressions of metric component weights on content percentile.

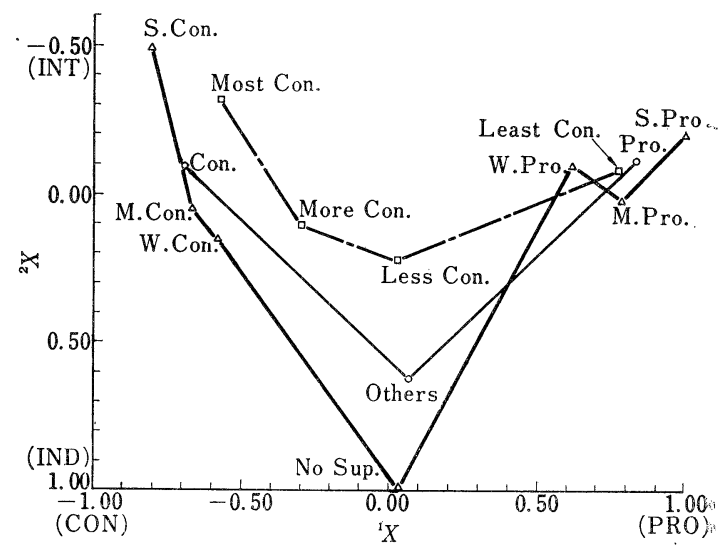

FIG. 6 Regressions of second principal comporent weights on metric component weights.

392 の註 18 及び 3 の(3)参照.

40 この点については, INTENSITY との関連に和い て, 次項で更にふれる.

41 これはパーセンタイル算出の手続きが割愛でき, 実 用上たいへん便利である。

422 の註 19 及び 3 の(4)参照.

43 乙かも, INTENSITY が最低の值をとるとき，丁 度 CONTENT が殆えど0の值をとる。これは前述の。 『引矢法』によって子「第 1 解が十なら“革新的”一な ら“保守的”」という解釈（7の註 40 参照）が当を得て。 いることを示していよう。 
TABLE 5

Metric component weights on PRO-CON items

(Tokyo)

\begin{tabular}{|c|c|c|c|}
\hline PRO-CON items & Frequency & C. P. ${ }^{\dagger}$ & M. C. W. ${ }^{\dagger \dagger}$ \\
\hline $\begin{array}{l}\text { Strong conservative } \\
\text { (S. Con.) }\end{array}$ & 66 & 12.2 & -0.821 \\
\hline $\begin{array}{c}\text { Medium conservative } \\
\text { (M. Con.) }\end{array}$ & 153 & 40.6 & -0.681 \\
\hline $\begin{array}{l}\text { Weak conservative } \\
\text { (W. Con.) }\end{array}$ & 51 & 50.1 & -0.593 \\
\hline No support (No. Sup.) & 37 & 57.0 & 0.018 \\
\hline $\begin{array}{c}\text { Weak progressive } \\
\text { (W. Pro.) }\end{array}$ & 49 & 66.1 & 0.610 \\
\hline $\begin{array}{c}\text { Medium progressive } \\
\text { (M. Pro.) }\end{array}$ & 112 & 86.9 & 0.780 \\
\hline $\begin{array}{c}\text { Strong progressive } \\
\text { (S. Pro.) }\end{array}$ & 71 & 100.0 & 0.996 \\
\hline Conservative (C) & 252 & 46.8 & -0.709 \\
\hline No support $(\mathrm{N})$ & 77 & 61.1 & 0.062 \\
\hline Progressive $(\mathrm{P})$ & 210 & 100.0 & 0.828 \\
\hline $\begin{array}{c}\text { Most conservative } \\
\text { (Most Con.) }\end{array}$ & 101 & 18.7 & -0.585 \\
\hline $\begin{array}{c}\text { More conservative } \\
\text { (More Con.) }\end{array}$ & 168 & 49.9 & -0.310 \\
\hline $\begin{array}{c}\text { Less conservative } \\
\text { (Less Con.) }\end{array}$ & 128 & 78.6 & 0.012 \\
\hline $\begin{array}{c}\text { Least conservative } \\
\text { (Least Con.) }\end{array}$ & 142 & 100.0 & 0.772 \\
\hline
\end{tabular}

$\dagger$ C. P.: Cumulative percent

i† M.C.W.: Metric component weights

全く同様の手繶きにより, 第 3 解のウェイトの第 1 解 のウェイトへの回帰をとったものが，Fig.7で女る，

ここで最も興味ある事実は，今まで極めて類似の回㷌 型を示してきたまつのアイテム（Fig。 5，6 参照）が，

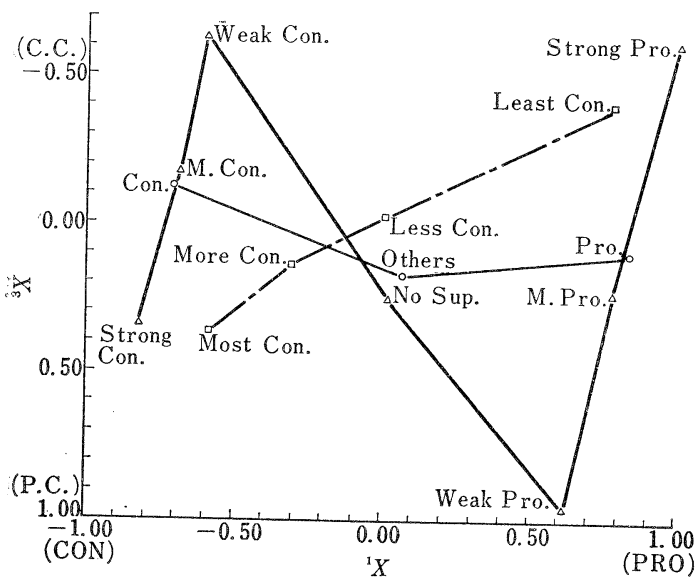

FIG. 7 Regressions of third principal component weights of metric component weights.
ここに至ってはじめて全く異った回帰型を示したという ことである。

すなわち，Fig。 7 より，「政党支持」は，第 3 解とは 殆えぞ関連がない。「保守度」に関しては，第 3 解は第 1 解による情報以上の殆んど何ものも与光得ない（単調な る直線回帰故, 第 1 解より第 3 解は一義的に定まる).

ところが「政党支持強度」のみに特いて，第 3 解は第 1 解とは別の次元でありながら（相関係数 $\div 0)$ ，乙かも 実に綺麗な関連を示している(相関比 $\div 1.0)$ ことがわか る。しかも，その回帰の型は，まさにN字型をなして利 り，Guttman が完全尺度をなすアイテムに颓いて発掘 した，“第三の次元”すなわち CLOSURE に相当するも のであることがわかる。

この第三の次元は，従来しばしばいわれてきた「安定 一不安定」とかっ「批判的一埋没的」とかいった次元とはや や異り，方向性をもっている点に，特徴がある。すなお ら，Fig.7 より，“強い革新は保守 (に対して) 批判的, 中位革新は無批判的, 弱小革新は革新(自己)批判的. そ の裹返しとして，弱い保守は保守（自己）批判的，中位 保守は無批判的, 強い保守は革新(に対して) 批判的” いう，連続的連関の様相が読みとれる．更に各ふの保守 層と革新層のなかでの批判の程度叔よび型がかなり異な ることも，推定され，與味深い44.

以上の議論を要約すると, 次のようにい方よう。なず 今回の資料は，すべて不完全尺度であるにもかかわらず, Guttman が完全尺度の場合に限り確定した三つの成分 CONTENT, INTENSITY, CLOSURE が，確認され た ${ }^{45}$.「政党支持態度」の領域に和けるこれら三つの成分 は，「方向」「強度」「方向批判」ともいうべき三つの次 元であり，これら三つの成分により最も效率よく，態度 の構造が記述されることが, 数学的に明らかにされた.

これら三つの「心理学的基本次元」を用いて，種々の 政治的態度の構造执よび具体的政治行動の類型を, 次に, 記述・考察することにより，この方法論拈よびモデルの 吟味と評価を試みることにしたい（続く）

\section{引用 文 献}

飽戸 弘 $1963 \mathrm{a}$ 多次元解析法と数量化法, $\langle 1\rangle$, サンケイ・アド・マンスリー，15，38-42.

飽戸 弘 $1964 \mathrm{~b} \mathrm{SD}$ 法の再検討, 一一適用の問題点

44 例えば，弱い革新の自己批判が最も篊しく，強い保 守の革新批判が最も緩いこと, 強い革新の保守批判々弱 い保守の自己批判の程度が，その中間に位し，ほぼ同し 程度であることなど。

45 即ち，3.で提唱した方法論が，理論的だけでなく実 際的に現実の資料にあてはまることが岀りうるという証 抛が示されたと考えられる。 
と改善への試論—KYOWA AD REVIEW 15, 15-22.

飽戸 弘 $1964 \mathrm{a}$ 多次元解析法と数量化法, $\langle 2\rangle$, サンケイ・アド・マンスリー，16，60-63.

飽戸 弘 $1964 \mathrm{~b}$ 数量化理論一一社会行動研究に括け る適用の效用と限界について一一年報社会心理 学, 5, 73-103.

飽戸 弘 $1964 \mathrm{c}$ 均衡の理論と変革の理論 (その一), サンケイ・アド・マンスリー，21，58-62.

餲戸 弘・加留部清 - 览島和人 1964 投票行動の研究 一-1963 年東京都知事選素材にして—, 年報社会心理学， 5, 246-247.

飽戸 弘 $1965 \mathrm{a}$ 政治的態度の構造関する研究, 日 本心理学会第 29 回大会発表諭文集, p. 339 。

飽戸 弘 $1965 \mathrm{~b}$ 政治的態度の構造に関する研究一社 会的特性との関連一, 日本社会心理学会第6 回 大会研究発表プリント集, 14-16,

飽戸 弘・池田 諒・本多忠頼 1965 広告特性に関す る研究, 日本社会心理学会第 6 回大会研究発表 プリント集, 9-11.

Berelson, B. R., Lazarsfeld, P.F., \& McPhee, W. N. 1954 Voting : A study of opinion formation in a presidential campaign. Chicago: Univ. Chicago Press.

Campbell, A., Gurin, G., \& Miller, W.E. 1954 The voter decides. Evanston I11 : Row Peterson.

Campbell, A., Converse, E.C., Miller, W.E., \& Stokes, D.E. 1960 The American Voter. New York : John Wiley.

Cantril, H. 1951 The psychology of social movement. New York: John Wiley.

Carlson, H. B. 1934 Attitudes of undergraduate students. J. soc. psychol., 5, 202-212.

Edwards, A.L. 1957 Techniques of attitude scale construction. New York : Appleton-CenturyCrofts.

Eulan, H., \& Schneider, P. 1956 Dimensions of political involvement. Publ., Opin. Quart., $\mathrm{XX}, 128-142$.

Eysenck, H.J. 1951 Primary social attitudes as related to social class and political party. J. Sociol., 2, 198-219.

Eysenck, H.J. 1953 a The structure of human personality. London : Methuen.

Eysenck, H. J. 1953 b Primary social attitudes : A comparison of attitude patterns in England, Germany and Sweden. J. abnorm. soc. Psychol., 48, 563-568.

Eysenck, H.J. 1954 The psychology of politics. London: Routledge \& Kegan Paul.

藤野 武・岡路市郎・福島正治 1953 社会的態度の因 子分析的研究, 北海道学芸大学紀要, 4,2 号, $1-30$.

Ferguson, L. W. 1939 Primary social attitudes.
J.Psychol., 8, 217-223.

Ferguson, L. W, 1940 The measurement of primary social attitudes. J. Psychol., 10, 119-203, 福武直(編) 1960 日本人の社会意識 三一書房.

Guttman, L. 1941 The quantification of a class of attributes: A theory and method of scale construction. [In Horst, P., Wallin, P., Guttman, L., Wallin, F. B., Clausen, J.A., Reed, R. B., Richardson, M. W., \& Rosenthal, E. The prediction of personal adjustment. New York : Social Science Research Council. Pp. 319-348.

Guttman, L. 1950 a The principal components of scale analysis. In Stouffer, S. A., Guttman, L., Suchman,E.A., Lazarsfeld, P.F., Star, S.A., \& Clausen, J.A. Measurement and prediction. Princeton., N. J. : Princeton Univ. Press. Pp. 312-361.

Guttman, L. 1950 b Relation of scalogram analysis to the other techniques. (Ibid, 172212.)

Guttman, L. 1954 The principal components of scalable attitude. In Lazarsfeld, P.F. (Ed.) Mathematical thinking in the social sciences. Glencoe, I11 : The Free Press. 216-257.

Hayashi, C. 1950 On the quantification of qualitative data from the mathematico-statistical point of view. (An Approach for Applying this Method to the Parole Prediction).

Ann. Inst. Statis. Math., 2, No. 1, 35-47.

Hayashi, C. 1952 On the prediction of phenomena from qualitative data and the quantification of qualitative data from the mathematicostatistical point of view. Ann. Inst. Statis. Math. No.2, 69-98.

Hayashi, C. 1954 Multidimentional quantification, -with the application to analysis of social phenomena-. Ann. Inst. Statist. Math. 5, No. 2, $121-143$.

林知已夫 - 池内 一 - 水原泰介 - 大塩俊介 - 佐野勝男 1954 態度数量化の一方法について——測定法 と数量化理論—, 統計数理研究所巢報, 1 , 第 2 号, 5-40.

林知已夫・高倉節子・牧田 稔 - 斎藤定良 1958 態度 数量化の一方法 II- 政治的態度の分析を素 材として—, 統計数理研究所彙報, 6 , 第 1 号, $1-39$.

林知已夫 1959 数量化之予測に関する根本概念 統計 数理研究所彙報, 7 , 第 1 号, 43-64.

林知已夫・高倉節子 1964 予測に関する実証的研究 一一選举予測の方法論—— 統計数理研究所彙 報， 12 ，第 1 号， $9-86$.

林恵海教授還暦記念論文集 1956 日本社会学の課題 有斐閣。 
Hayes, H. P. 1939 The interrelations of poiltical attitudes, III, General factors in political issues, J. soc. Psychol., 10, 379-398.

日高六郎・升味準之輔・高橋 徹 1954 旧意識の温存 々変容. 遠山茂樹編 日本資本主義講座 9 , 岩波書店，163-268.

日高六郎(編) 1955 政治と経済の心理学 河出書房.

日高六郎・高橋 徹・城戸浩太郎・綿貫譲治 1955 労 働者とマス・コミュニケーション過程東京大 学新聞研究所紀要, 4, 65-108.

日高六郎 1960 a 現代イデオロギー 勁草書房.

日高六郎 $1960 \mathrm{~b}$ イデオロギー・社会心理・社会的性 格 現代イデオロギー，勁草書房，3-20.

日高六郎 $1960 \mathrm{c}$ 社会心理学的研究に和ける問題点 現代イデオロギー, 勁草書房, 200-207.

日高六郎 - 福島真吾 - 大島太郎 - 松下圭一・飽戸 弘 1964 政党支持々政治意識の動向についての調 査平和経済計画会議.

Himmelstrand, U. 1960 Verbal attitudes and behavior. Publ. Opin Quart., XXIV, No.2, 224-250.

池内 一 1949 ソシアルダイナミックスの問題 心研 20, 22-29.

池内 - 1953 選举投票の社会心理学的背景 新聞学 評論. 2, 163--188.

池内 - 1960 政治意識に対する社会心理学的接近 一一政党支持態度の分析を中心として——年 報社会心理学 創刊号 勁草書房, 67-92.

池内一・掛川々み子 1961 政治的無関心 川島武宜 (編) 経済と政治の心理，中山書店 184-183.

Johnson, H. M. 1942 A preliminary study of social attitudes, Brit. J. educ. Psychol., 12, 183.

Katz, D. 1960 The functional approach to the study of attitudes. Publ. Opin. Quart. XXIV, 163-204.

Katz, D., \& Stotland, E. 1959 A preliminary statement to a theory of attitude structure and change. In Koch, S. (Ed.) Pshchology: A study of science. Vol.3, New York: McGraw-Hill. Pp. 423-475.

河村豊次・四方焳子 1960 社会的態度の発達 心理学 評論, 4 巻, 1 号, 146-165.

木下富雄・三宅一郎・間場寿一 1964 異るレベルの選 挙に括ける投票行動の研究 (四) (七) (九) (十) 一一政党支持態度を支党る諸意識・態度一 法学論叢, 75 巻, 3 号, $113-150,76$ 巻, 3 号, 90-134, 76 巻, 5 号, $76-102,76$ 巻, 6 号, 90-136.

城戸浩太郎 1955 人間性の社会的基盤 日高六郎(編) 政治と経済の心理学 河出書房, Pp. 138-171.

Kornhauser, A., Mayer, A. J., \& Sheppard, H. L. 1956 When labor votes: A study of autoworkers, New York: University Books.

倉沢 進 1959 都市化と都会人の社会的性格 社会学
評論, 36 .

京極純一 1952 現代日本に和ける政治的行動様式 （上）（中）（下） 思想 9 月号, $869-889,10$ 月号， 983-999，12 月号，1285-1300.

京極純一・升味準之輔 1935 政治意識に拈ける前進と 停滞 年報政治学, 108-139.

京極純一 1958 政治意識の変容と分化 岡義武(編)現 代日本の政治過程 岩波書店, Pp. 442-508.

Lane, R.E. 1959 Political life: Why People get involved in politics. Glencoe, I11. : The Free Press.

Lasswell, H. D., \& Kaplan, A. 1952 Power and society: A framework for political Inquiry. London : Routledge \& Kegan Paul.

Lazarsfeld, P. F. (Ed.) 1954 Mathematical Thinking in the social sciences. Glemcoe, Ill. : The Free Press.

Lazarsfeld, P. F., Berelson, B, \& Gaudet, H. 1944 The people's choice, New York: Duell Sloan \& Pearce.

Lipset, S. M., Lazarsfeld, P.F., Barton, A. H., \& Linz, J. 1954 The psychology of votingAn analysis of political behavior. In Lindsey (Ed.) Handbook of social psychology, Vol. II, Cambridge, Mass : Addison-Wesley, 1124-1175.（邦訳，綿貫譲治 1957 投票の 心理——投票行動の分析——社会心理学講座, 8, 又すず書勏 第一分冊.)

Meton, R.K. 1957 Social theory and social Structure. Glencoe, Ill. : The Free Press. (邦訳 森 東吾・森好夫・金沢 実・中島竜太郎 1961 社会理論と社会構造 みすず書沱)。

三宅一郎 1963 アメリカ二大政党の組織単位としての 政党支持者集団——政党同一化の性格々機 能——法学論叢, 74 巻, 1 号, 62-118.

三宅一郎 1964 政治意識構造論の試み 日本政治学会 1964 年度研究報告要旨.

永井陽之助 1955 政治を動かするの日高六郎(編) 政治之経済の心理学 河出書房, Pp. 6-58.

西平直喜 1962 現代日本青年の社会意識構造 (1) 教 育心理学年報 第 2 集.

西平直喜 1963 現代日本青年の社会態度の構造（その II）教育心理学年報 第 3 集.

岡部慶三 1959 政治意識 —マス・メディアとの関 連に拈いて——理学評論, 3, No. 1, 4247.

岡田直之 1960 投票行動の社会心理学的分析 年報社 会心理学 創刊号 勁草書房, 171-188.

岡田直之 1965 憲法改正をめぐる国民世論の基調と動 向 成城大学記念論文集, 451-499.

Parsons, T., \& Shils, E. A. (Eds.) 1954 Toward a general theory of action. Cambridge, Mass.: Harvard Univ. Press.（邦訳, 永井道雄・作 田啓一・橋本 真 1960 行為の総合理論をめ 
ざして 日本評論新社).

Riesman, D. 1950 The lonely crowd: A study of the changing American character. New Haven, Conn. : Yale Univ. Press. (邦訳, 佐々木徹 郎・鈴木幸寿・谷田部文吉 1955 孤独なる群 衆みすず書房).

Riesman, D. 1961 同上簡約版 New Haven Conn.: Yale Univ. Press. (邦訳, 加藤秀俊 1964 孤独な群衆 みすず書房).

Riesman, D, \& Glazer, N. 1950 Criteria for political apathy. In New York Goldner, A. W. (Ed.) Studies in leadership. Harper and Brothets, $547-554$.

Rosenberg, M. J. 1960 a A structural theory of attitude dynamics. Publ.Opin.Quart., XXIV, $319-340$.

Rosenberg, M. J. 1960 b Attitude organization and change: An analysis of consistency among attitude components. New Haven, Conn.: Yale Univ. Press.

Sanai, M. 1950 A factorial study of attitudes. $J$. soc. Psychol., 31, 167-182.

Sanai, M. 1951 An experimental study of social attitudes, J. soc. Psychol., 34, 235-264.

Sarnoff, I. 1960 Psychoanalytic theory and social attitudes. Publ. Opin. Quart., XXIV, 251 -279 .

島田一男 1963 社会心理学の基底一態度の心理学 一大日本図書.

Smith, M. B. 1947 The personal setting of public opinions: A study of attitudes toward Russia. Publ. Opin. Quart., XI, 507-523.

Stouffer, S. A., Guttman, L., Suchman, E. A., Lazarsfeld, P.F., Star, S. A., \& Clausen, J. A. 1950 Measurement and prediction. Princeton, N. J. : Princeton Univ. Press. "Studies in social psychology in world war
II" series, Vol. IV.

Suchman, E. A. 1950 the intensity component in attitude and opinion research. Ibid, 213-276.

杉 政孝・城戸浩太郎 1954 社会意識の構造 社会学 評論, 13,14 .

高橋 徹 1956 イデオロギー研究に関するノート 林 恵海教授還暦記念論文集 日本社会学の課題 有斐閣, $155-177$.

高橋 徹 - 岡部慶三・荒瀬 豊 - 青井和夫 - 綿貫譫治 ・ 稲葉三千男・竹内郁郎・本間康平・岡田直之・ 藤竹 暁・掛川トミ子・早川善治郎・倉沢 進 1958 都市勤労市民層の政治意識とコミュニケ ーション行動 東京大学新聞研究所紀要 7,83 . -182 .

高橋 徹 1960 生活意識々政治意識 年報社会心理学 創刊号 勁草畫房, 93-120.

田中国夫 1960 社会心理学に打ける態度測定の問題 心理学評論 4, No. 2, 266-279.

田中国夫 $1964 \mathrm{a}$ 日本人の社会的態度 誠信書房.

田中国夫 $1964 \mathrm{~b}$ 社会的態度とイデオロギーとの関係 について—態度構造研究に関する間題点の提: 示——年報社会心理学 $5,104-124$.

田中国夫・松山安雄 1960 社会的態度の階層心理学的 研究 (1) 年報社会心理学 創刊号 勁草書房, 141-170. $\quad$ Rev. 41, 1-32.

Thurstone, L. L. 1934 Vector of the mind. Psychol. 辻村 明 - 稲葉三千男 - 竹内郁郎 - 本間康平 - 岡田直之 1959 投票行動に拈ける意識構造東京大学新 聞研究所紀要 8, 55-125. 「閣, 247-259.

綿貫譲治 1956 学働者意識研究の批判と課題 林恵海 教授還暦記念論文集 日本社会学の課題 有斐 綿貫熼治・城戸浩太郎 1955 社会生活のピラミッド 日高六郎(編) 政治と経済の心理学 河出書房, Pp. 80-132. 「月号, 879-886.

綿貫譲治 1961 政治・社会・文化 (上)(中)(下) 思 想, 2 月号, $121-131,3$ 月号, 326-337, 7 安田三郎 1960 社会調查ハンドブック 有裴閣。

1965. 10. 8 受稿—

\section{STUDY ON THE STRUCTURE OF POLITICAL ATTITUDE I HIROSHI AKUTO \\ University of Tokyo}

\section{ABSTRACT}

This paper (1) proposes a new method for studying attitude by revised application of a series of statistico-mathematical models, i.e. the "Quantification Theory" which were developed by Guttman, L. and
Hayashi, C.; (2) presents an empirical descripiton of the structure of political attitude and the pattern of political behavior of the Japanese based on the new method; and (3) tests the various kinds of models that have been proposed so far on the structure of political and social attitude. 
Of these models, a great many tend to be either subjective or speculative in their methodology. On the other hand, are usually based on a measurement developed through factor analysis.

In an attempt not only to avoid subjectiveness or speculativeness, but also to revise many of the theoretical deficiencies in factor analysis, the present paper applied "Quantification Theory" to structural models of political attitude.

As a result, a description was made concerning both the structure of politcal attitude and the pattern of political behavior.

\section{Method:}

Subjects: Electorate of both sexes over 20 years of age.

Sample size: 800 subjects, Tokyo (23 wards), and 840 subjects, Chiba City, Chiba Prefecture.

Questionnaires: A total of 44 items are included which are to be broken down as follows:

(1) Political behavior (7 items)

(2) Political attitude (25 items)

(3) Social attitude (4 items)

(4) Demographic information(8 items) Procedures:

(1) The subjects were interviewed individually and answered to the questionnaires that were given orally.

(2) To meet the limitation of the computor capacity, 29 items were selected out of the aforementioned 44 items on the basis of the significance of the items, which ranged over 100 categories. Calculation was made through Guttman-Hayashi multidimensional quantification method.

Result: Three dimensional vectors were allocated to each of these categories (Table 1 and 2). For the cluster of items on the "party identification" the regressions of the metric component weights, the second component weights, and the third component weights on content percentile (direction of party identification) showed monotonic, U-shaped and N-shaped curves (Fig. 5, Fig. 6 and Fig. 7).

Disscussion: The above results lead the author to make the following interpretations.

1. The structure of the political attitude of the Japanese is to be observed most efficiently in terms of the three basic dimensions; (1) Progressive vs. Conservative (Direction), (2) Indifferent vs. Interested (Indifferency), and (3) Progressive Critical vs. Conservative Critical (Stability).

2. The "content", "intensity" and "closure" are both mathematically (theoretically) and psychologically (empirically) identified by Guttman, L. as basic functions of the attitude when clusters of items are perfectly scalable. The present study successfully extacted the same three basic functions by applying newly proposed methodology despite the fact that not all the items were scalable. Furthermore, it was assumed that the above three basic dimensions, i.e., (1) Progressive vs. Conservative, (2) Indifferent vs. Interested, and (3) Progressive Critical vs. Conservative Critical, are themselves the basic functions of attitudes in the area of "party indentification". In other words, they are "content", "intensity" and "closure" in the field of "party identification".

In the subsequent discussions, an attempt will be made to describe and consider, by applying the above three basic dimensions, a pattern of specific political behavior and a structure of political attitude.

(To be continued.) 